\title{
COMPARATIVE ANALYSES OF BIODIESEL PRODUCED FROM NEEM AND JATROPHA SEED OIL
}

\author{
Ibrahim, I. S., ${ }^{1}$ Abdullahi, I. T. ${ }^{2}$ and Muhammad, F. Y. ${ }^{3}$ \\ ${ }^{1}$ Department of Biochemistry, Federal University Dutse \\ ${ }^{1}$ Department of Biotechnology, Federal University Dutse \\ ${ }^{2}$ Department of Medicine, Muhammadu Abdullahi Wase Teaching Hospital Kano \\ *Correspondence author: salihu.ibrahim@fud.edu.ng
}

\begin{abstract}
Biodiesel is derived from triglycerides by transesterification reaction with alcohol (ethanol or methanol), and has classified as a renewable, biodegradable, and nontoxic fuel. Several methods for biodiesel production have been developed, among which transesterification using alkali-catalysis gives high levels of conversion of triglycerides to their corresponding methyl esters in short reaction times. This study was conducted to extract the neem and Jatropha oil for the production of biodiesel using alkali-catalyzed reaction. The samples were subjected to reaction with sodium hydroxide ( $\mathrm{NaOH}), 0.2: 1$ $w / \mathrm{v}$ methanol (MeOH) to oil mole ratio, reaction temperature of $6^{\circ} \mathrm{C}$, and 30 min reaction time. The final biodiesel yield obtained was $47.5 \%$ and $45.5 \%$ from the neem and the jatropha oil sample respectively. The basic physiochemical properties of the jatropha methyl ester produced from both jatropha oil samples were found to be within the ASTM D6751 specified limits.
\end{abstract}

Keywords: Transesterification, neem, biodiesel, jatropha oil; free fatty acid (FFA)

\section{INTRODUCTION}

Biodiesel can be produced from both edible and non-edible oil as well as animal fats (Ramadhas et al., 2005) and can be derived from a variety of sources including, vegetable oils, animal fats, neem seed oil, Jatropha seed oil and waste cooking oil (Demirbas, 2008). One of the most promising processes to convert vegetable oil into methyl ester is the transesterification, in which alcohol reacts with triglycerides of fatty acids (vegetable oil) in the presence of catalyst. The vegetable oil used for biodiesel production might contain free fatty acids which will enhance saponification reaction as side reaction during the transesterification process. Previous studies have shown that, on the basis of mass, biodiesel has an energy content of about $12 \%$ less than that of petroleum diesel fuel. It reduces unburned hydrocarbons, carbon monoxide, and increase oxides of nitrogen than diesel-fueled engine(Hasan et el., 2013).

Neem tree (Azadirachta indica) seeds have $40 \%$ oil as such it can be used for the production of biodiesel. The Neem oil is characterized with bitter test, strong odor that is said to combine theodors of peanut and garlic is generally light to dark brown in color (Hasan et al., 2013). The
Jatropha oil has certain advantages compared to other seed oil which include low acidity of the oil, good oxidation stability; low viscosity and it have better cooling properties. In addition, the free fatty acids, density and viscosity of the oil are stable within the period of storage (Pandey et al. 2012).

\section{MATERIALS AND METHODS}

Material

Mortar and pestle, round bottom flask, conical flask, beaker, weighing balance, spatula, water bath, thermometer, oven, magnetic stirrer, separating funnel, retort stand, pippete, burrete, measuring cylinder, $\mathrm{pH}$ meter electrode, condenser, n-hexane, hydrochloric acid, methanol, ethanol, sodium hydroxide, potassium hydroxide, distilled water, phenolphthalein indicator, ethanolic potassium hydroxide and buffer solution.

\section{Sample Collection and Treatment}

The seeds of neem tree were collected at male hostel, Federal University Dutse, Jigawa state while that of Jatropha was collected at the Technology Business Incubation Center, Farm center Tarauni local government, Kano state. 
BAJOPAS Volume 12 Number 2, December, 2019

\section{Preparation of Seed}

Both the neem and Jatropha seeds were ovendried until the casing split and shell of the seeds shade. The shaded seeds were further dried for about two weeks in order to reduce the moisture content. The shell was separated from the cotyledon using tray which blows away the cover this is done in order to achieve very high yield. There seeds were crushed using mortar and pestle in order to weaken the cell wall so as to release castor fat for oil extraction.

\section{Oil Extraction}

Neem and Jatropha oil were extracted using two solvent (n-hexane and ethanol) with ratio Neem seed powder and Jatropha seed powder weight to solvent volume of $1: 3$. The solution is allowed to stand for two weeks and is filtered using separating funnel.filtrates were collected in a beaker and air-dry for 2 weeks to evaporate the solvent. Then the oils were weighed to calculate the oil yield in the extract.

\section{Transesterification Reaction}

About 20ml of each of neem and Jatropha oils were separately weighed and added to a beaker. Sodium hydroxide $(0.2 \mathrm{~g})$ was dissolved in $50 \mathrm{ml}$ methanol contained in a conical flask and in to the each of the beakers. The mixtures were then heated at $60^{\circ} \mathrm{C}$ and stirred using magnetic stirrer for about $30 \mathrm{~min}$ after they were allowed to cool at room temperature. The mixtures formed two layers with the esters in the upper layer while the lower layer contained impurities and glycerol. The methyl ester was separated from the glycerol using separating funnel with methanol. The methyl esters were washed, and the impurities and glycerol were removed by spraying hot distilled water $(10 \% \mathrm{v} / \mathrm{v})$ over the surface of each of the two mixtures and stirring. The biodiesel (yellow in color) contained in the upper layer was separated from the lower layer (Singh et al., 2006). The yield of methyl esters was calculated using the formula:

Yield of methyl esters (\%)

$=\frac{\text { Grams of methyl esters produced }}{\text { grams of oil used in the reaction }}$

$$
\times 100
$$

\section{Characterization of the Neem and Jatropha Biodiesel}

Standard test method was used to determine the physicochemical property of the biodiesel. These properties were determined and compared with ASTM. The properties; \% yield, specific gravity, free fatty acid value, saponification value and density were determined using standard procedures.

\section{Determination of Specific Gravity}

A 50ml empty beaker was weighed and recorded as $W_{0}$. The beaker is filled with oil, stopper inserted and weighed and recorded as $\mathrm{W}_{1}$. The oil was then substituted with water after washing and drying the bottle and weighed and recorded as $W_{2}$. (Akpanet al., 2006)

The expression for specific gravity is:

Sp.gr $=\frac{(\mathrm{W} 1-\mathrm{W} 0)}{(\mathrm{W} 2-\mathrm{W} 0)}$

Where;

$\left(W_{1}-W_{0}\right)=$ the mass of the substance

$\left(W_{2}-W_{0}\right)=$ the mass of equal volume of water.

\section{Determination of Free Fatty Acid Values}

About $25 \mathrm{ml}$ of methanol is added to $1.5 \mathrm{~g}$ of the oil sample contained in a flask. The mixture was boiled in a water bath and then allowed to cool. Two drops of phenolphthalein indicator was added to the solution. The mixture was titrated with $0.1 \mathrm{~N} \mathrm{NaOH}$ and shake thoroughly to obtain homogenous mixture until it attained an end point which was noted a dark pink color. The volume of $0.1 \mathrm{~N} \mathrm{NaOH}$ required to reach the end point was recorded as $\mathrm{V}$. (Prithviraj and Naik 2015).

Free fatty acid was calculated as follows;

$$
\% \mathrm{FFA}=\frac{\mathrm{V} \times 0.0282}{\text { weight of sample }} \times 100
$$

\section{Determination of Saponification Value}

Oil sample $(2 \mathrm{~g})$ was weighed into a conical flask and $25 \mathrm{ml}$ of $0.1 \mathrm{M}$ ethanolic potassium hydroxide $(\mathrm{KOH})$ was added. The mixture was constantly stirred and gently boiled for $60 \mathrm{~min}$. A reflux condenser was placed on the flask containing the mixture. Few drops of phenolphthalein indicator were added to the warm solution and titrated with $0.5 \mathrm{M} \mathrm{HCl}$ to the end point until pink color of the indicator disappeared. The same procedure was used for other samples and blank. Saponification value is calculated as in below (Akpanet al., 2006; Kyari, 2008):

$\mathrm{S} . \mathrm{V}=\frac{56.1 \mathrm{~N}(\mathrm{~V} 0-\mathrm{V} 1)}{\mathrm{M}}$

Where;

$\mathrm{VO}=$ volume of the solution used for blank test

$\mathrm{VI}=$ volume of the solution used for determination

$\mathrm{N}=$ Actual normality of the $\mathrm{HCl}$ used

$M=$ Mass of the sample

\section{pH value}

Each sample $(2 \mathrm{~g})$ was poured into $25 \mathrm{ml}$ glass beaker, $13 \mathrm{ml}$ of hot distilled water was added to each sample and stirred slowly. The mixtures were then cooled in a cold-water bath to $25^{\circ} \mathrm{C}$. The $\mathrm{pH}$ meter electrode was standardized with buffer solution and then immersed into the sample and $\mathrm{pH}$ value was measured (Akpan et al., 2006). 
BAJOPAS Volume 12 Number 2, December, 2019 RESULTS AND DISCUSSION

The percentage yield of extracted neem seed oil and Jatropha seed oil was found to be $47.5 \%$ and $45.5 \%$, respectively. The results indicate that seeds are good source of oil which could be used for biodiesel production. The yield obtained is slightly lower than that reported by Kathirvelu et al., 2014). In this study, biodiesel from neem and Jatropha oil were formed from the basecatalysed transesterification, and methyl esters were obtained in the range of 47.5 and $45.5 \%$. This shows that the neem seeds were found to have high biodiesel content $(47.5 \%)$ than the Jatropha oil as shown in table 1 . The acid value obtained for both the neem and Jatropha biodiesel were $2.7 \mathrm{mg} / \mathrm{KOH} / \mathrm{g}$ and $1.6 \mathrm{mg} / \mathrm{KOH} / \mathrm{g}$ this shows that both the biodiesel have high acid value than the ASTM standard which is $0.8 \mathrm{mg} / \mathrm{KOH} / \mathrm{g}$ as reported by Nkolika et al., (2012). High acid value favors soap formation and the separation of products will be difficult and as a result it has low yield of the biodiesel product as reported by Crabbe et al. (2001). The saponification value of both neem and Jatropha have reduced compared with diesel value of $191 \mathrm{mgKOH} / \mathrm{g}$ which is very reasonable range in comparison with ASTM standard as reported by Banu et al., (2018). The specific gravity for both the biodiesel are within the range of standard value as reported by Prithviraj et al., (2015). The higher the specific gravity of a fuel the greater the mass of fuel injected into the engine and hence more power as reported by Rao et al. (2010).

Table 1 Physicochemical Properties of neem and Jatropha biodiesel

\begin{tabular}{lllll}
\hline Parameters & $\begin{array}{l}\text { Neem } \\
\text { biodiesel }\end{array}$ & $\begin{array}{l}\text { Jatropha } \\
\text { biodiesel }\end{array}$ & $\begin{array}{l}\text { ASTM } \\
\text { standard }\end{array}$ & Diesel \\
\hline \%yield & 47.5 & 45.5 & ----- & - \\
FFA $(\mathrm{mg} \mathrm{KOH} / \mathrm{g})$ & 1.7 & 2.7 & $<0.80$ & ---- \\
Saponification value $\quad(\mathrm{mgKOH} / \mathrm{g})$ & 120.6 & 154 & ----- & 191 \\
Specific gravity $(\mathrm{gm} / \mathrm{ml})$ & 0.80 & 0.84 & 0.88 & $0.82-0.845$ \\
Density $\mathrm{g} / \mathrm{ml}$ & 0.9 & 0.84 & $0.9 \max$ & 0.85 \\
\hline
\end{tabular}

\section{CONCLUSION}

Both the Jatropha and neem seed oil can be used as an alternative for biodiesel production. Based on the comparison of characteristic fuel properties of biodiesel of both the neem and

\section{REFERENCE}

Akpan UG, Jimoh A, and Mohammed AD (2006). Extraction, Characterization and Modification of Castor Seed Oil. Leonardo Journal of Sciences 8: $43-52$.

Banu DH, Shallangwa BT, Joseph I, Magu OT, Hitler L and Ahmed S (2018). Biodiesel Production from Neem Seed (Azadirachta indica) Oil using calcium Oxide as Heterogeneous Catalyst. Journal of Physical Chemistry \&Biophysics $\quad$ volume8: 266. doi:10.4172/2161-0398.1000266

Crabbe E C N, Nolasco-Hipolito G, Kobayashi K Sonomoto and AIshizaki, Process Biochemistry 37(1) (2001) 65-71.

Demirbas A (2008). Biodiesel From Vegetable Oils Via Esterification in Supercritical Methanol.Energy Conversion Management. 43(23):49-56.

Hasan Ali MD, Mohammad Mashud, Rowsonozzaman Rubel MD, Rakibul Hossain Ahmad. (2013). Procedia Engineering 56 ( 2013) 625-630

Kathirvelu S, Shenbaga VMN, Neela K, Mayilsamy K and Krishnaswamy (2014).ARPN Journal of Engineering and Applied Science: WwW.arpnjournals.com

Kyari MZ (2008). Extraction and characterization of seed oils. Int. Agrophysiscs, 22: 139-142.
Jatropha with the ASTM standard and diesel fuel properties, the result indicates that the produced fuels are comparable with diesel and can become an alternative for the source of biodiesel.

Nkolika CI, ObiajuluBCO and Uwaoma AO. Comparative Study of the Physicochemical Characterization of Some Oils as Potential Feedstock for Biodiesel Production.International Scholarly Research Notices.Article ID 621518 | 5 | https://doi.org/10.5402/2012/621518

Pandey VC, Singhb K, Singhc JK, Kumard A, Singhb B, Singha RP (2012) Jatrophacurcas: A potential biofuel plant for sustainable environmental development. Renewable and Sustainable Energy Reviews 16 (2012) 2870- 2883

Prithviraj Bhandare, Naik GR (2015) Physico-Chemical Properties of Biodiesel Produced from Neemoi. International Letters of Chemistry, Physics and Astronomy Vol. 47, pp 40-48

Ramadhas AS, Jayaraj S, Muraleedharan C (2005) Biodiesel production from high FFA rubber seed oil. Fue/ 84 335-340

Rao G. L. N, Ramadhas AS, Nullusamy N, and Sakthivel, P (2010) .Relationship Among The Physical Properties of Biodiesel and Engine Fuel System Design Requirement.International Journal of Energy and Environment.1(5): 919 - 926.

Singh $P$ K, A K Kumar, S Sethi, http://dspace.nitrkl.ac.in/dspac. (2006). 